\title{
Efektifitas Yoga Ketawa terhadap Penurunan Tekanan Darah pada Lansia dengan Hipertensi Derajat II di Panti Wredha Salib Putih Salatiga
}

\author{
Nehemia Bangkit Pangestu ${ }^{1}$, Maria Dyah Kurniasari ${ }^{2}$, Antonius Tri Wibowo ${ }^{3}$ \\ ${ }^{1,2,3}$ Program Studi Ilmu Keperawatan, Universitas Kristen Satya Wacana Salatiga \\ Email: maria.dyah@staff.uksw.edu
}

\begin{abstract}
The Effectiveness of Laughter Yoga as Non-Pharmacological Therapy in The Elderly with Grade 2 Hypertension in Panti Wredha Salib Putih Salatiga. Old age is often attacked the cardiovascular diseases such as hypertension. Ministry of Health Republic of Indonesia (2012) states that hypertension is one of the most influential risk factors for the incidence of heart disease and blood vessels. High blood pressure continuously increases the burden of the arteries slowly. The arteries undergo hardening process becomes thick and rigid, thus reducing its elasticity. Hypertension can also lead to heart disease because if high blood pressure is left without regular treatment, the heart must pump very strongly to push blood into the arteries, over time the walls of the heart muscle become thicker. An abnormally enlarged heart is an unhealthy heart because the heart becomes stiff and the beat tends to be irregular. This will make pumping less effective and eventually lead to heart failure. Pharmacologic treatment using drugs have the risk of side effects. The purpose of this study was to analyze the effectiveness of laughter yoga as non-pharmacological therapy in the elderly with hypertension by measuring the difference in blood pressure before and after being treated laughter yoga. Quantitative experimental research with pretest-posttest with a control group design. The sample used purposive sampling that is 20 elderly that is 10 elderly with treatment and 10 elderly as a control. The instrument was used analog tensimeter. Wilxocon different test results obtained from pretreatment group of post systole and diastole p-value 0,007 and 0,003. While in control group of pre-post systole and diastole p-value 0,831 and 0,084 . Laughter yoga effectively against decreased blood pressure in the elderly with grade 2 hypertension at the Panti Wredha Salib Putih Salatiga.
\end{abstract}

Keywords: Elderly, Hypertension, Laughter yoga

\begin{abstract}
Abstrak: Efektifitas Yoga Ketawa terhadap Penurunan Tekanan Darah pada Lansia dengan Hipertensi Derajat II di Panti Wredha Salib Putih Salatiga. Masa lanjut usia rentan sekali dengan berbagai penyakit degeneratif, salah satunya penyakit kardiovaskular seperti hipertensi atau tekanan darah tinggi. Departemen Kesehatan Repubik Indonesia (2012) menyatakan hipertensi merupakan salah satu faktor risiko yang paling berpengaruh terhadap kejadian penyakit jantung dan pembuluh darah. Tekanan darah tinggi yang secara terus menerus menambah beban pembuluh arteri secara perlahan-lahan. Arteri mengalami proses pengerasan menjadi tebal dan kaku, sehingga mengurangi elastisitasnya. Hipertensi juga bisa mengakibatkan penyakit jantung karena jika tekanan darah tinggi dibiarkan tanpa perawatan tetap, jantung harus memompa dengan sangat kuat untuk mendorong darah ke dalam arteri, lama-kelamaan dinding otot jantung akan menjadi tebal. Sebuah jantung yang membesar abnormal adalah jantung yang tidak sehat karena jantung menjadi kaku dan irama denyutnya cenderung tidak teratur. Hal ini akan menjadikan pemompaan kurang efektif dan akhirnya akan menyebabkan kegagalan jantung. Penanganan farmakologi menggunakan obat dengan resiko adanya efek samping. Tujuan dari penelitian ini yaitu menganalisa efektifitas yoga ketawa sebagai terapi non farmakologi pada lansia dengan hipertensi dengan mengukur perbedaan tekanan darah sebelum dan sesudah diberi perlakuan yoga ketawa. Penelitian kuantitatif eksperimen dengan rancangan penelitian pretest-posttest with control group. Sampel penelitian menggunakan purposive sampling yaitu 20 lansia yaitu 10 lansia dengan perlakuan dan 10 lansia sebagai kontrol.Intrumen yang digunakan yaitu tensimeter analog. Uji beda Wilxocon, hasil yang didapat dari kelompok perlakuan pre post systole dan diastole pvalue 0,007 dan 0,003. Sedangkan pada kelompok kontrol pre post systole dan diastole p-value 0,831 dan 0,084 . Yoga ketawa efektif terhadap penurunan tekanan darah pada lansia dengan hipertensi derajat II di Panti Wredha Salib Putih Salatiga.
\end{abstract}

Kata kunci: Lanjut usia, Hipertensi, Yoga ketawa

Data Badan Pusat Statistika (BPS) (2014), jiwa, setara dengan 8,03 persen dari seluruh jumlah lansia di Indonesia mencapai 20,24 juta penduduk Indonesia tahun 2014. Angka proyeksi 
penduduk tahun 2014, jumlah lansia di Provinsi Jawa Tengah meningkat menjadi 3,83 juta jiwa atau sebesar 11,43 persen dibandingkan tahun 2013 sebesar 8,9 persen. Data dari dinas kesehatan Kota pada tahun 2015 diperkirakan jumlah lansia mencapai 61.332 orang atau $31 \%$ dari jumlah penduduk. Masa lanjut usia ini rentan sekali dengan berbagai penyakit degeneratif, salah satunya penyakit kardiovaskular. Jenis penyakit kardiovaskular yang sering sekali lansia alami yaitu hipertensi atau tekanan darah tinggi.

Departemen Kesehatan Repubik Indonesia (2012) menyatakan hipertensi merupakan salah satu faktor risiko yang paling berpengaruh terhadap kejadian penyakit jantung dan pembuluh darah.Tekanan darah tinggi yang secara terus menerus menambah beban pembuluh arteri secara perlahan-lahan. Arteri mengalami proses pengerasan menjadi tebal dan kaku, sehingga mengurangi elastisitasnya.

Hipertensi juga bisa mengakibatkan penyakit jantung karena jika tekanan darah tinggi dibiarkan tanpa perawatan tetap, jantung harus memompa dengan sangat kuat untuk mendorong darah ke dalam arteri, lama-kelamaan dinding otot jantung akan menjadi tebal. Sebuah jantung yang membesar abnormal adalah jantung yang tidak sehat karena jantung menjadi kaku dan irama denyutnya cenderung tidak teratur. Hal ini akan menjadikan pemompaan kurang efektif dan akhirnya akan menyebabkan kegagalan jantung (Wahyuni, 2015).

Data Kementrian Kesehatan RI (2012) juga menyatakan penyakit hipertensi termasuk penyakit dengan jumlah kasus terbanyak pada pasien rawat jalan yaitu 80.615 kasus. Hipertensi merupakan penyakit penyebab kematian peringkat ketiga di Indonesia dengan CFR (Case Fatality Rate) sebesar 4,81\%. Di Jawa Tengah, mengalami kenaikan jumlah penderita hipertensi pada tahun 2011, pada tahun 2010 terjadi 562,117 kasus dan pada tahun 2011 menjadi 634,860 kasus.

Data-data di atas menunjukkan tingginya angka lansia dengan hipertensi. Dimana kita telah ketahui sebelumnya bahwa hipertensi merupakan permasalahan serius yang perlu ditangani dengan cara yang tepat. Penanganan hipertensi sendiri dilakukan bertujuan untuk mencegah terjadinya kecacatan dan kematian dengan mencapai dan mempertahankan tekanan darah di bawah 140/90 $\mathrm{mmHg}$.

Suzanne (2013) menyatakan ada dua cara penanganan yang dilakukan untuk mengobati hipertensi yaitu farmakologis dan non farmakologis. Penanganan farmakologis yaitu dengan menggunakan obat-obatan antihipertensi yang terbukti dapat menurunkan tekanan darah. Obat-obatan yang biasa digunakan dalam mengatasi hipertensi yaitu captopril dan amlodipine. Penggunaan obat-obatan ini tentu saja dapat menimbulkan efek samping, efek samping yang dapat timbul yaitu merasa lelah atau pusing, jantung berdegup kencang, merasa mual dan tidak nyaman di bagian perut, dan pergelangan kaki membengkak. Di samping pemberian obat antihipertensi yang memiliki efek samping, terdapat penanganan non farmakologi yang hampir tidak memiliki efek samping untuk penderita hipertensi.

Penanganan non farmakologis atau disebut juga dengan modifikasi gaya hidup yang meliputi berhenti merokok, mengurangi kelebihan berat badan, menghindari alkohol, modifikasi diet, menghindari atau mengurangi konsumsi minuman keras, mengurangi konsumsi minuman kaya kafein, seperti kopi, teh, atau cola. Tingginya kafein dalam kopi mampu membuat tekanan darah seseorang yang menderita hipertensi akan naik sebanyak 3-4 kali. Hal ini disebabkan karena saat kafein masuk ke dalam aliran darah, maka hormon adrenal yang membuat penikmat kopi selalu terjaga akan meningkat, sehingga tekanan darah yang meningkat pun akan terpengaruh dan semakin meninggi (Kusumaningrum, 2015). Penanganan hipertensi non farmalogi selanjutnya yang mencakup psikis antara lain mengurangi stres, olahraga, terapi musik, terapi tawa dan istirahat.

Dari beberapa jenis penanganan hipertensi non farmakologis tersebut, salah satu yang saat ini mulai menjadi trend dilakukan adalah yoga ketawa. Kataria (2012) dalam Penny (2012) menyebut tawa merupakan tindakan paling sehat yang bisa dilakukan, obat terbaik. Salah satu jenis terapi tawa yaitu yoga ketawa. Desinta \& Ramdhani (2013) menyebut terapi tawa adalah salah satu cara untuk mencapai kondisi rileks. Tertawa merupakan paduan dari peningkatan sistem saraf simpatik dan juga penurunan kerja sistem saraf simpatetik. Peningkatannya berfungsi untuk memberikan tenaga bagi gerakan pada tubuh, namun hal ini kemudian juga diikuti oleh penurunan sistem saraf simpatetik yang salah satunya disebabkan oleh adanya perubahan kondisi otot yang menjadi lebih rileks, dan pengurangan pemecahan terhadap nitric oxide (senyawa kimia yang penting untuk tranportasi sinyal listrik di dalam sel-sel) yang membawa pada pelebaran pembuluh darah.

Terapi tawa menggunakan pendekatan perilaku melalui metode conditioning. Terapi tawa dilakukan dengan cara mengajak klien melakukan aktivitas tertawa dengan melibatkan 
perilaku dan gerakan tubuh yaitu dengan melakukan latihan teknik tawa untuk memunculkan tertawa alami lewat perilakunya sendiri tanpa adanya humor. Desinta \& Ramdhani (2013) menyebut bahwa individu akan berlatih melakukan gerakan motorik dan suara tertawa, yang akhirnya berakhir pada kondisi fisiologis (meningkatnya sistem saraf parasimpatetis dan menurunnya sistem saraf simpatis).

Pada penelitian sebelumnya yang dilakukan oleh Wijayanti (2012) menemukan bahwa yoga ketawa pernah diterapkan untuk mengatasi stres pada mahasiswa semester akhir.Hasil dari penelitian tersebut adanya efektifitas yoga ketawa terhadap stres pada mahasiswa semester akhir. Pada penelitian ini, peneliti ingin meneliti tentang efektifitas yoga ketawa untuk lansia dengan hipertensi pada sebuah panti wredha di Salatiga Jawa Tengah. Penelitian sebelumnya menggunakan mahasiswa semester akhir untuk perlakuannya, sedangkan penelitian kali ini dilakukan pada lansia dan tidak mengalami stres sehingga penelitian ini berbeda dengan penelitian sebelumnya.

Sementara itu, hasil dari wawancara awal dengan kepala Panti Wreda Salib Putih Salatiga, ditemukan bahwa terdapat 30 lansia dan $70 \%$ lansia di sana menderita hipertensi. Selama ini, pengobatan farmakologi/obat-obatan yang diperoleh para lansia di Panti Wreda Salib Putih Salatiga yang menderita hipertensi adalah obat amlodipine yang menimbulkan efek samping seperti merasa lelah atau pusing, jantung berdegup kencang, merasa mual dan tidak nyaman di bagian perut dan pergelangan kaki membengkak. Penanganan non farmakologi seperti senam yang diadakan satu bulan sekali, bersosial dengan para penghuni wisma. Dari hal tersebut, peneliti ingin menerapkan penanganan non farmakologis dalam hal ini yoga ketawa untuk menurunkan tekanan darah pada lansia dengan hipertensi grade II dan sama-sama berusia 50-80 tahun. Peneliti ingin mengetahui apakah yoga tawa efektif untuk menurunkan tekanan darah pada lansia dengan hipertensi. Oleh karena itu peneliti akan melakukan penelitian ini di Panti Wreda Salib Putih Salatiga.

\section{METODE}

Jenis penelitian ini adalah kuantitatif eksperimen dengan rancangan penelitian pretestposttest with control group. Populasi dalam kelompok ini adalah Lansia Panti Wreda Salib Putih dan Panti Wreda Maria Martha Salatiga yang berjumlah 30 lansia. Penentuan sampel menggunakan teknik purposive sampling/ berdasarkan karakteristik seperti rentan usia 6085 tahun, lansia telah didiagnosa oleh doktersebagai penderita hipertensi, tidak sedang tirah baring dan bisa melakukan berbagai aktifitas secara mandiri, suku Jawa, berjenis kelamin laki-laki dan perempuan.Pengambilan data dilakukan pada kedua kelompok. Pengumpulan data dilakukan dengan instrumen alat pengukur tekanan darah pada kelompok perlakuan sejumlah 10 lansia (Lansia Panti Wreda Salib Putih, Salatiga) dan kelompok kontrol sejumlah 10 lansia (Lansia Panti Wreda Maria Martha Salatiga) dengan pre test (pemeriksaan tekanan darah) pada tahap awal serta posttest (pemeriksaan tekanan darah) pada tahap akhir setelah periode perlakuan/intervensi.

Instrumen lain yang digunakan dalam penelitian ini, kelompok perlakuan diberikan intervensi yaitu terapi yoga tawa, sedangkan kelompok kontrol tidak dilakukan intervensi. Intervensi yoga ketawa dilakukan selama 15 kali selama satu bulan, pada bulan April 2016 (Kataria M, 2004). Pemberi intervensi melakukan pelatihan resmi dan memiliki lisensi ijin untuk memberikan terapi yoga ketawa. Proses intervensi ini berlangsung selama 15-20 menit. Berikut langkah-langkah yang digunakan saat melakukan yoga ketawa (Kataria, 2004):

1. Pemanasan/Peregangan

Pemanasan yang dimaksud lansia posisi duduk lalu menggelengkan kepala ke kiri dan ke kanan, menundukkan kepala dan ke atas, lalu kaki dan tangan di gerakkan.

2. Tepuk tangan

Tepuk tangan sambil mengucapkan HoHo-HaHa-Ha dengan durasi waktu \pm 1 menit dan setelah selesai mengambil nafas dalam dengan mengangkat tangan setinggi bahu.

\section{Senam ketawa}

a) Tawa sapaan: Tertawa dengan mengatupkan kedua telapak tangan dan menyapa holywood kepada teman di samping kiri dan kanan. Setelah selesai mengucapkan "very good, very good yee" dan diakhiri dengan nafas dalam sebanyak 3 kali.

b) Tawa singa: Julurkan lidah sepenuhnya dengan mata terbuka lebar dan tangan teracung seperti cakar singa dan tertawa. Setelah selesai mengucapkan "very good, very good yee" dan diakhiri dengan nafas dalam sebanyak 3 kali.

c) Tawa ponsel: Berpura-puralah memegang sebuah ponsel dan coba untuk tertawa sambil membuat berbagai gerakan kepala 
dan tangan serta berkeliling dan berjabat tangan dengan orang yang berbeda. Setelah selesai mengucapkan "very good, very good yee" dan diakhiri dengan nafas dalam sebanyak 3 kali.

d) Tawa Apresiasi: Berkeliling (jika bisa berdiri) sambil mengacungkan dua jempol sambil tertawa untuk menyampaikan penghargaan kepada peserta lainya. Setelah selesai mengucapkan "very good, very good yee" dan diakhiri dengan nafas dalam sebanyak 3 kali.

e) Tawa Pesawat: rentangkan lengan seperti sebuah pesawat terbang dan terbanglah berkeliling sambil tertawa (dilakukan apabila lansia bisa berdiri dan bejalan). Setelah selesai mengucapkan "very good, very good yee" dan diakhiri dengan nafas dalam sebanyak 3 kali.

f) Tawa bill: pura-pura membuka tagihan kartu kredit yang besarnya diluar dugaan. Lihat dan kemudian tertawalah secara histeris. Tunjukkan kepada orang lain tagihan itu dan tertawalah bersama membuang stres. Setelah selesai mengucapkan "very good, very good yee" dan diakhiri dengan nafas dalam sebanyak 3 kali.

g) Tawa membuat susu: berpura puralah memegang dua gelas susu dan sesuai abaaba leader tuangkan susu dari satu gelas ke gelas lain sambil mengucap "aeeee..." dan kemudian tuangan kembali ke dalam gelas pertama sambil mengucap "aeeee..." setelah itu tertawa dan meminum susu itu. Setelah selesai mengucapkan "very good, very good yee" dan diakhiri dengan nafas dalam sebanyak 3 kali.

h) Tawa high-ten: tos dengan kedua belah tangan dan tertawa. Setelah selesai mengucapkan "very good, very good yee" dan diakhiri dengan nafas dalam sebanyak 3 kali.

4. Relaksasi

a) Mengambil nafas dalam dengan mengangkat tangan sebatas bahu, dan nafas di keluarkan dengan menurunkan tangan sambil mengucap "hooo..".

b) Mengambil nafas dalam dengan mengangkat tangan sebatas bahu, dan nafas di keluarkan dengan menurunkan tangan sambil mengucap "haaa..".

c) Mengambil nafas dalam dengan mengangkat tangan sebatas bahu, dan nafas di keluarkan dengan menurunkan tangan sambil mengucap "hmm..".

\section{HASIL}

Hasil penelitian menunjukkan, terjadinya penurunan tekanan darah baik systole maupun diastole setelah diberikan terapi yoga ketawa. Penurunan angka ini kemudian dilakukan uji beda dengan menggunakan Uji Wilcoxon untuk melihat signifikansi penurunan angka yang didapat. Tabel 1 akan menggambarkan sebaran data da hasil uji beda Wilcoxon antara tekanan darah hasil pemeriksaan pre test dan post test. Perubahan tekanan darah pada kelompok perlakuan akan disajikan pada Tabel 1 berikut ini.

\begin{tabular}{|c|c|c|c|}
\hline $\begin{array}{r}\text { Tabel 1. Distri } \\
\text { Systol } \\
\text { Wilco } \\
\text { Post } 7 \\
\end{array}$ & $\begin{array}{l}\text { si } \\
\text { Diastole } \\
\text { n Peme } \\
\text { t pada K }\end{array}$ & $\begin{array}{l}\text { Tekanan } \\
\text { dan } \\
\text { riksaan } P \\
\text { elompok }\end{array}$ & $\begin{array}{l}\text { Darah } \\
\text { Uji } \quad \text { Beda } \\
\text { re test dan } \\
\text { Perlakuan } \\
\end{array}$ \\
\hline Variabel & Mean & $\begin{array}{l}\text { Min- } \\
\text { Maks }\end{array}$ & $\begin{array}{c}p \text {-value } \\
\text { Uji Beda } \\
\text { Berpasangan } \\
\text { Wilcoxon } \\
\end{array}$ \\
\hline \multicolumn{4}{|c|}{ Systole } \\
\hline $\begin{array}{l}\text { Tekanan Darah } \\
\text { Systole Pre test }\end{array}$ & 156 & $140-190$ & \multirow{2}{*}{0,007} \\
\hline $\begin{array}{l}\text { Tekanan Darah } \\
\text { Systole Post test }\end{array}$ & 130 & $90-100$ & \\
\hline \multicolumn{4}{|c|}{ Diastole } \\
\hline $\begin{array}{l}\text { Tekanan Darah } \\
\text { Diastole Pre test }\end{array}$ & 93 & $110-150$ & \multirow{2}{*}{0.03} \\
\hline $\begin{array}{l}\text { Tekanan Darah } \\
\text { Diastole Post test }\end{array}$ & 84 & $80-90$ & \\
\hline
\end{tabular}

Hasil pemeriksaan tekanan darah systoleldiastole pemeriksaa pre test yang ditunjukkan pada Tabel 1 menujukkan bahwa angka tekanan darah systole dan diastole tergolong dalam penyakit hipertensi baik. Data pre test ini menjadi data awal peneliti melakukan intervensi terapi yoga ketawa. Tabel 1 juga menunjukkan data hasil pemeriksaan tekanan darah post test. Data post test adalah data hasil pemeriksaan tekanan darah yang didapatkan setelah peneliti memberikan perlakuan yoga ketawa selama 15 kali.

Uji beda signifikansi penurunan tekanan darah systoleldiastole dari pre test hingga post test pada Tabel 1 menunjukkan adanya perbedaan yang signifikan. Terapi yoga ketawa yang dilakukan pada kelompok perlakuan menunjukkan efektifnya terapi non farmakologi yoga ketawa pada penderita hipertensi setelah $15 \mathrm{x}$ diberikan.

Peneliti juga melakukan analisa data tekanan darah systoleldiastole pre test dan post test pada kelompok kontrol. Tabel 2 akan meggambarkan sebaran data dan menunjukkan 
bahwa tidak terjadinya perubahan yang signifikan antara tekanan darah pre test dan post test.

\begin{tabular}{ll} 
Tabel 2. Distribusi & Tekanan $\begin{array}{r}\text { Darah } \\
\text { Systole/Diastole Pre test dan Pos Test } \\
\text { Pada Kelompok Kontrol }\end{array}$ \\
\hline
\end{tabular}

\begin{tabular}{|c|c|c|c|}
\hline Variabel & Mean & $\begin{array}{l}\text { Min- } \\
\text { Maks }\end{array}$ & $\begin{array}{c}p \text {-value } \\
\text { Uji Beda } \\
\text { Berpasangan } \\
\text { Wilcoxon }\end{array}$ \\
\hline \multicolumn{4}{|c|}{ Systole } \\
\hline $\begin{array}{l}\text { Tekanan Darah } \\
\text { Systole Pre test }\end{array}$ & 144 & $\begin{array}{r}120- \\
170\end{array}$ & \multirow{2}{*}{0.831} \\
\hline $\begin{array}{l}\text { Tekanan Darah } \\
\text { Systole Post test }\end{array}$ & 145 & $80-90$ & \\
\hline \multicolumn{4}{|c|}{ Diastole } \\
\hline $\begin{array}{c}\text { Tekanan Darah } \\
\text { Diastole Pre test }\end{array}$ & 88 & $\begin{array}{r}130- \\
170\end{array}$ & \multirow{2}{*}{0.084} \\
\hline $\begin{array}{c}\text { Tekanan Darah } \\
\text { Diastole Post test }\end{array}$ & 82 & $\begin{array}{l}70- \\
100\end{array}$ & \\
\hline
\end{tabular}

Hasil pemeriksaan pada kelompok kontrol, tidak mendapatkan perubahan yang signifikan saat diberikan uji beda. Jika dilihat dari rerata, bahkan terjadi kenaikan satu angka pada pemeriksaan systole pada pre test dan post test.

Peneliti juga melakukan uji beda kelompok tidak berpasangan, yakni tekanan darah systoleldiastole pada kelompok perlakuan dan kelompok kontrol. Tabel 3 akan mendeskripsikan sebaran data dan uji beda tidak berpasangan dengan menggunakan uji Mann-Whitney.

Tabel 3. Analisis Tekanan Darah Systole/ Diastole Pretest dan Systole/Diastole Post Test Menggunakan Uji Beda Mann-Whitney pada Kelompok Perlakuan dan Kontrol

\begin{tabular}{|c|c|c|c|}
\hline Variabel & Mean & $\begin{array}{l}\text { Min- } \\
\text { Maks }\end{array}$ & $\begin{array}{l}\text { Mann- } \\
\text { Whitney }\end{array}$ \\
\hline $\begin{array}{l}\text { Pre systole } \\
\text { Kelompok perlakuan }\end{array}$ & 156 & $\begin{array}{r}140- \\
190\end{array}$ & \multirow{2}{*}{0.130} \\
\hline $\begin{array}{l}\text { Pre systole } \\
\text { Kelompok kontrol }\end{array}$ & 144 & $\begin{array}{r}120- \\
170\end{array}$ & \\
\hline $\begin{array}{l}\text { Pre diastole } \\
\text { Kelompok perlakuan }\end{array}$ & 88 & $80-90$ & \multirow{2}{*}{0.028} \\
\hline $\begin{array}{l}\text { Pre diastole } \\
\text { Kelompok kontrol }\end{array}$ & 88 & $80-90$ & \\
\hline $\begin{array}{l}\text { Post systole } \\
\text { Kelompok perlakuan }\end{array}$ & 130.00 & $\begin{array}{r}110- \\
150\end{array}$ & \multirow{2}{*}{0.01} \\
\hline $\begin{array}{l}\text { Post systole } \\
\text { Kelompok kontrol }\end{array}$ & 145.00 & $\begin{array}{r}130- \\
170\end{array}$ & \\
\hline $\begin{array}{l}\text { Post diastole } \\
\text { Kelompok perlakuan }\end{array}$ & 84.00 & $80-90$ & \multirow{2}{*}{0.449} \\
\hline $\begin{array}{l}\text { Post diastole } \\
\text { Kelompok kontrol }\end{array}$ & 82.00 & $70-100$ & \\
\hline
\end{tabular}

Uji beda tekanan darah systole post test pada kelompok perlakuan dan kelompok kontrol menunjukkan bahwa terjadi perbedaan. Terapi yoga ketawa pada uji tidak berpasangan hanya efektif terhadap tekanan darah systole yakni post test systole antara kelompok perlakuan dan kelompok kontrol $(p=0.01)$.

\section{PEMBAHASAN}

Penanganan hipertensi menurut Susilo \& Wulandari (2011) dalam Hermanto (2014) adalah dengan cara mengatasi keadaan obesitas atau menurunkan berat badan, mengurangi asupan garam ke dalam darah, menciptakan keadaan rileks seperti meditasi, yoga, atau hypnosis yang mengontrol sistem saraf untuk mengendalikan tekanan darah, melakukan olah raga secara rutin, berhenti merokok, dan berhenti mengkonsumsi alkohol.

Penanganan yang diberikan kepada partisipan untuk penelitian ini yaitu penanganan non farmakologis berupa yoga ketawa. Tabel 1 menunjukkan bahwa adanya penurunan tekanan darah setelah dilakukan yoga ketawa, hal ini bisa dilihat dari nilai rata-rata/mean tekanan systole dan diastole sesudah perlakuan yoga ketawa selama tiga minggu, yaitu dengan tekanan systole $130 \mathrm{mmHg}$ dan tekanan diastole $84 \mathrm{mmHg}$. Hasil ini didukung dengan hasil analisis menggunakan uji wilcoxon pada tabel 1 menunjukkan $p$-value tekanan systole sebelum dan sesudah yoga ketawa yaitu $p$-value $=0,007$ dan tekanan diastole $p$-value $=0,003$. Hasil tersebut memberi arti bahwa adanya perubahan tekanan darah pada partisipan sesudah diberikan perlakuan yoga ketawa. Hasil penelitian Dr. Michael Miller dalam Dewi (2015) menyebut bahwa dengan tertawa dapat mengembangkan/memperluas pembuluh darah yang menyebabkan meningkatnya sirkulasi dan mengurangi tekanan darah. Tawa meningkatkan sirkulasi dam meningkatkan suplai oksigen.Dalam percobaanya, telah membuktikan bahwa ada penurunan tekanan darah $10-20 \mathrm{mmHg}$ setelah 10 menit tertawa. Hasil penelitian Dr. Michael Miller dalam Dewi (2015) menunjukan keselarasan dengan hasil penelitian ini. Jika dilihat dari konsep terapi yoga ketawa bahwa terapi ini memiliki sesi relaksasi untuk para partisipan setelah melakukan senam tawa. Lebih dalam lagi bahwa, Chaplin (2005) dalam Sagala (2013) menyebut relaksasi adalah kembalinya otot dalam keadaan istirahat setelah mengalami peregangan sedangkan terapi relaksasi adalah suatu bentuk terapi dengan menekankan suatu usaha atau mengajarkan pasien bagaimana cara beristirahat dan santai dengan asumsi bahwa 
istirahatnya otot-otot dapat membantu mengurangi tegangan psikologis.

Menurut asumsi peneliti, keadaan rileks ini dibutuhkan oleh pasien hipertensi. Stimulus adanya stressor atau hal yang memicu ketegangan pada pasien hipertensi akan memicu naiknya tekanan darah. Dalam penelitian ini, pasien hipertensi dapat mengalami penurunan tekanan darah terjadi erat hubungannya dengan yoga ketawa yang akan membuat seseorang menjadi lebih rileks. Keadaan rileks ini memicu penurunan fungsi sistem limbik yang merupakan pusat pengaturan emosi. Pada akhirnya dapat menurunkan tekanan darah yang tinggi. Selain itu, yoga ketawa sendiri memicu adanya peningkatan hormon endorfin yang sangat dibutuhkan oleh tubuh.

Seperti yang telah kita ketahui bahwa hormon endorfin akan menghambat produksi hormon-hormon stres yang berlebih (Kataria, 2004). Kataria, 2004 menyebutkan yoga ketawa dapat juga memperbaiki sirkulasi darah dan pasokan oksigen ke otot-otot jantung, sehingga penggumpalan darah akan berkurang. Keadaan rileks yang membuat penurunan fungsi limbik sebagai pusat emosi serta produksi hormon endofrin sebagai penghambat hormon stres ini dimungkinkan menjadi mekanisme fungsi terapi yoga ketawa.

Dampak lain selain penurunan tekanan darah pada lansia dengan hipertensi tereksplore dengan wawancara singkat. Hasil wawancara singkat menunjukkan bahawa para lansia yang sebelumnya mengaku kesulitan untuk tidur di malam hari, dapat cepat tidur dan nyenyak setelah mengikuti sesi yoga ketawa sebanyak 3 kali.Para lansia juga mengatakan bahwa partisipan dalam hal ini lansia merasa jauh lebih tenang dan rileks. Yoga ketawa menghasilkan hormon endorfin menyebabkan semua ketegangan-ketegangan otot mampu dikendurkan, sehingga rasa tenang dapat dirasakan oleh lansia. Hal ini diperkuat dari hasil penelitian Fitriani (2014) yang menjelaskan bahwa dimana terapi ini akan membuat partisipan merasa tenang dan rileks sehingga dapat meningkatkan kualitas tidur dari partisipan. Menurut peneliti, kualitas tidur yang baik membuat pasien hipertensi dapat memulihkan sel-sel yang rusak sehingga dapat memperbaiki kerja jantungdan menurunkan tekanan darah.

Penelitian lain yang dilakukan oleh Hae-jin \& Chang-ho17 dalam Fitriani (2014) diketahui bahwa tertawa dapat digunakan sebagai intervensi pada lansia untuk menurunkan derajat insomnia dan gangguan tidur lainnya. Tertawa akan merangsang pelepasan hormon endorfin, yang disebut juga sebagai morfin tubuh. Menurut peneliti, keterkaitan morfin dengan tekanan darah adalah, bahwa produksi morfin dapat memperlancar sirkulasi darah sehingga seluruh jaringan tubuh mendapatkan nutrisi dan oksigen secara maksimal disamping rasa rileks yang didapat. Hasil keseluruhan menunjukan, terdapat penurunan tekanan darah yang signifikan, hal ini sangat menguatkan tentang teori hormon endorfin yang dapat menurunkan tekanan darah pada lansia karena lansia menjadi rileks dan otot kendur dan membuat tenang, terlihat lebih serta jauh lebih mudah tidur disaat malam hari. Perlu pengembangan penelitian yang melakukan pemeriksaanvariabel hormon-hormon yang dapat menentukan tingkat stres dan rileksnya tubuh manusia dalam penelitian yoga ketawa.

Penelitian ini juga melakukan uji beda antar kelompok pre dan post systole maupun diastole. Uji beda ini menggunakan uji beda Mann-Whitney. Hasilnya menunjukkan pada post perlakuan, tekanan systole dapat berbeda antar kelompok dapat dilihat pada Tabel 3 yaitu $p$ value $=0,01$, karena dengan perlakuan yoga ketawa, maka dapat menimbulkan kadar oksigen dalam darah meningkat, membantu meningkatkan suasana hati, menurunkan hormon stres, meningkatkan aktivitas kekebalan tubuh, menurunkan kolesterol jahat dan tekanan darah sistolik serta meningkatkan kolesterol baik, Berk et al (1996) dalam Tage (2016). Tekanan diastole kedua kelompok tidak signifikan, dapat dilihat pada tabel 4.16 yaitu $0,449>0,05$. Hal ini dikarenakan pembuluh darah pada lansia mengalami kekakuan atau sudah tidak memiliki elastisitas yang baik karena adanya proses penuaan, sehingga tekanan diastole masingmasing kelompok hampir sama, Medicinesia (2011). Dari hasil penelitian serta pembahasan yang mendalam, dapat diambil kesimpulan bahwa perlakuan yoga ketawa yang diberikan kepada lansia dengan hipertensi di Panti Wredha Salib Putih Salatiga terlihat efektif untuk menurunkan tekanan darah.

\section{SIMPULAN}

Kesimpulan dari hasil penelitian ini adalah yoga ketawa efektif dalam menurunkan tekanan darah pada lansia dengan hipertensi derajat II dengan adanya perbedaan tekanan darah pada systole dan diastole sebelum dan sesudah perlakuan yoga ketawa di Panti Wredha Salib Putih Salatiga. 


\section{SARAN}

Bagi lansia yang terdiagnosa hipertensi yang dapat melakukan mobilisasi dengan baik dan tidak tirah baring dapat mengikuti terapi yoga ketawa yang dipandu oleh leader yang bersertifikasi. Bagi profesi keperawatan, yoga ketawa juga dapat menjadi intervensi dalam terapi komplementer dalam asuhan keperawatan keluarga atau komunitas. Dari hasil penelitian ini, penelitian selanjutnya dapat meneliti terapi yoga

\section{DAFTAR PUSTAKA}

Badan Pusat Statistik. 2014. Statistik Penduduk Lanjut Usia. Katalog BPS.

http://www.bps.go.id/website/pdf_publikas i/Statistik-Penduduk-Lanjut-Usia-2014.pdf (Diakses pada tanggal 27 Januari 2016).

BPS Jawa Tengah. 2014. Profil Lansia Jawa Tengah. Katalog BPS Jawa Tengah. http://jateng.bps.go.id/website/pdf_publika si/Profil-Lansia-Jawa-Tengah-2014--.pdf (Diakses pada 27 Januari 2016).

Departemen Kesehatan Republik Indonesia. 2012. Masalah Hipertensi di Indonesia. http://www.depkes.go.id/article/view/1909 /masalah-hipertensi-di-

indonesia.html\#sthash.DrYHdexL.dpuf

(Diakses pada tanggal 27 Januari 2016).

Desinta, S., \& Ramdhani, N. 2013. Terapi Tawa untuk Menurunkan Stres pada Penderita Hipertensi. Jurnal Psikologi, 40 (1), 15-27. http://jurnal.ugm.ac.id/jpsi/article/downloa d/7063/5515 (Diakses pada 4 Februari 2016).

Dewi, Emmy Liana. 2015. Laughter Yoga International University. Yogyakarta: Buku untuk kalangan sendiri.

Dinas Kesehatan Kota Salatiga. 2015. Peringatan Hari Lansia 2015.

http://www.dkksalatiga.org/info-kesehatan (Diakses pada 22 Februari 2016).

Fitriani, Dewi Caesaria. 2014. Pengaruh Terapi Tertawa Terhadap Derajat Insomnia Pada Lansia Di Dusun Jomegatan, Ngestiharjo, Kasihan, Bantul. Skripsi, PSIK UMY. thesis.umy.ac.id/datapublik/t34163.pdf. (Diakses tanggal 4 Februari 2016).

Hermanto, Jeri. 2014. Pengaruh Pemberian Meditasi Terhadap Penurunan Tekanan Darah Pada Lansia Dengan Hipertensi Di Unit Sosial Rehabilitasi Pucang Gading Semarang. Jurnal Keperawatan. http://web.unair.ac.id/admin/file/f_66363 Jurnal_Keperawatan_PENGARUH_PEMB ketawa dengan mengembangkan konsep penelitian seperti pengembangan variabel yang diujikan, contohnya pemeriksaan kolesterol, kualitas tidur lansia, stres/depresi) atau meluaskan area penelitian serta menambah frekuensi pemberian yoga ketawa agar bisa melihat efek-efek lain yang ditimbulkan dari penerapan yoga ketawa. Pengembangan penelitian ini dapat menjadi bahan analisa yang lebih mendalam.

ERIAN_ME.pdf (Diakses pada 09 Mei 2016).

Kataria. 2012. Curious About Laughter Yoga. http://www.laughteryoga.org/english/laugh teryoga (Diakses pada 4 Februari 2016).

Kataria. 2004. Laugh For No Reason (Terapi Tawa). Jakarta: Gramedia.

Kementerian Kesehatan RI. 2014. Situasi Dan Analisis Lanjut Usia. http://www.depkes.go.id/resources/downlo ad/pusdatin/infodatin/infodatin-lansia.pdf (Diakses pada 4 Februari 2016).

Kusumaningrum, Febrianti Diah. 2015. Ini Bahayanya Minum Kopi Bagi Si Penderita Hipertensi.

http://www.merdeka.com/sehat/inibahayanyaminum-kopi-bagi-si-penderitahipertensi.html (Diakses pada 16 Februari 2016).

Sagala, Masitah. 2013. Efek Pelatihan Relaksasi Untuk Menurunkan Stres Kerja pada Karyawan di PT. Madubaru Yogyakarta. EMPATHY Jurnal Fakultas Psikologi, 2 (1). http://www.jogjapress.com/index.php/EM PATHY/article/view/1542 (Diakses pada 24 Maret 2016).

Suzanne CS. 2001. Buku Ajar Keperawatan Medikal Bedah Brunner \& Suddarth. Volume 2, Edisi 8. Jakarta: EGC.

Tage, Petrus Kanisius Siga. 2016. Pengaruh Terapi Tertawa Terhadap Perubahan Tekanan Darah Pada Lansia Dengan Hipertensi Sistolik Terisolasi di Panti Sosial Budi Agung Kupang. Journal Unair. http://journal.unair.ac.id/downloadfullpapers-ijchnfad7c40937full.pdf (Diakses pada 23 Mei 2016).

Wahyuni, Tri. 2015. Cara Hipertensi Menyebabkan Gagal Jantung. http://www.cnnindonesia.com/ (Diakses pada 07 Februari 2016). 
Wijayanti, Putri H. 2012. Pengaruh Yoga Tawa Terhadap Kecemasan, Stres, dan Depresi Pada Mahasiswa Semester Akhir di Program Studi Ilmu Keperawatan Fakultas
Kedokteran Universitas Diponegoro. http://www.who.int/healthinfo/survey/agei ngdefnolder/en/ (Diakses pada Februari 2016). 